\title{
Forensic analysis and source partitioning of aliphatic hydrocarbon contaminants in surface sediments from the Niger Delta, Nigeria
}

\author{
Fubara, Ebirien Partrick ${ }^{1}$, Ekpo, Bassey Offiong ${ }^{2}$, Ekpa, Okon Douglas ${ }^{3}$ \\ ${ }^{1}$ Department of Chemistry, Benue State University, Makurdi, Nigeria \\ ${ }^{2}$ Exploration, Research \& Services Section, Research \& Development Division, NNPC, Port Harcourt, Nigeria \\ ${ }^{3}$ Environmental \& Petroleum Geochemistry Research Group (EPGRG), Department of Pure \& Applied Chemistry, University of Calabar, \\ Calabar, Nigeria
}

\section{Email address:}

ebifubs@yahoo.com (Fubara E. P.)

\section{To cite this article:}

Fubara, Ebirien Partrick, Ekpo, Bassey Offiong, Ekpa, Okon Douglas. Forensic Analysis and Source Partitioning of Aliphatic Hydrocarbon Contaminants in Surface Sediments from the Niger Delta, Nigeria. International Journal of Environmental Monitoring and Analysis. Vol. 2, No. 4, 2014, pp. 199-208. doi: 10.11648/j.ijema.20140204.13

\begin{abstract}
Forensic analyses and source partitioning modeling were used in characterizing aliphatic hydrocarbon contaminant compositions in surface sediments from coastal areas of the Niger Delta region of Nigeria. The Total Organic carbon (TOC) contents for the sediments ranged from 0.44 to $4.26 \%$ (mean $2.36 \pm 1.03$ ). The concentrations of total aliphatic hydrocarbon in the entire study area ranged from 1.65 to $61.34 \mathrm{mg} / \mathrm{kg}$ dry weight, with overall average of $21.52 \pm$ 22.00. The mean concentrations of aliphatic hydrocarbon $\left(\mathrm{C}_{16}-\mathrm{C}_{31}\right)$ for the sediments in the upper, middle and lower zones of the study area were in the ranges of $0.04-5.44 \mathrm{mg} / \mathrm{kg}, 0.04-4.91 \mathrm{mg} / \mathrm{kg}$ and $0.11-10.31 \mathrm{mg} / \mathrm{kg}$, respectively. CPI values in the broad range of $0.31-13.32$ for the entire stations is indicative of mixed hydrocarbon inputs. A predominance of odd/even carbon n-alkanes and UCM with different shapes and ranges were observed and suggest inputs from multiple sources. Source partitioning modeling using Factor analyses reduced the data set into three principal components (PCs) confirming inputs from biogenic, anthropogenic and microbial/bacterial sources.
\end{abstract}

Keywords: Forensic Analysis, Aliphatic Hydrocarbon, Sources, Factor Analysis, UCM, Niger Delta

\section{Introduction}

The global use of forensic environmental geochemistry (FEG) methodologies for differentiating various hydrocarbon fuels and solvents in environmentally altered samples has been reported. The methodologies have been used in numerous environmental cases throughout the United States of America to provide evidences in resolving legal disputes relating to the source identification of environmental contaminants ([1], [2]. In the context of natural resource damage or exposure assessments, advanced chemical fingerprinting (ACF) of hydrocarbonbased materials is an essential component of such assessments, particularly in the context of both definitive scientific determinations of damage causation and defensible litigation positions. Sediments are commonly used for the assessment of petroleum pollution in coastal aquatic system [3],[4],[5],[6]. This approach arises from the concept that sediments act as sink and provide an integrated picture of the events taking place in the water column. Sediments provide a dynamic and long-term reservoir for organic species. These organic species include lipids (solvent-soluble organic matter), such as hydrocarbons, fatty acids, alcohols and macromolecular organic matter. All these are derived from natural biogenic, geologic and industrial sources [7],[8],[9]. Lipid classes have been used as molecular tracers to understand the origin and reactivity of organic matter in marine ecosystem [10]. Predominant lipid classes may reflect the nature of source organisms and the conditions in the immediate environment such as limiting nutrient supply. The magnitude and rates of change in the molecular characteristics of various lipid classes and individual compounds at various depths (and in surface sediments) can therefore be used to apportion and track the overall transfer of primary producers from the euphotic zone to the benthic sediments [11]. In the coastal and 
marine environment, these aliphatic hydrocarbons are sequestered and preserved in surficial sediments. Their sources are either natural from photosynthesis by marine biota inhabiting the surface waters or anthropogenic from land run-off, fallout, and/or industrial inputs [9].

Hydrocarbon contaminants have been released, over the years, into the Niger Delta coastal environment from different sources such as untreated effluents, domestic sewages, animal droppings, bush/wood burning, atmospheric fallout, traffic boat engines and crude oil spills. Understanding contaminant hydrocarbon sources, transport and fate in estuaries is important as these are regions of both high pollution input and resource use. In spite of anthropogenic pressure, estuaries remain dynamic and productive ecosystem of immense ecological, environmental and economic value [12]. In order to distinguish and evaluate the different anthropogenic versus biogenic sources of organic matter in sediments, the aliphatic hydrocarbon composition of surficial sediments from various sources must be determined and the proportion of each identified in the samples. Study on the distributions and sources of aliphatic hydrocarbons and ketones in surface sediments from the Cross River estuary, Southeastern Niger Delta has been reported [13]. Fubara and others [14] have reported the predominances and source implications of even n-alkenes in surface sediments from coastal areas of the Niger Delta region. Even nalkane/alkene predominances [15] and predominance of ndocosane/docosene [16] have been reported for surface sediments from the Calabar River estuary, with the presence of unresolved complex mixture (UCM) indicating petroleum contamination at two stations along the estuary.

Information on the geochemical characterization, distribution, transport and fate of n-alkanes in Niger Delta coastal sediments is rather scanty and fragmentary. This is highly regrettable, especially given the maze of rivers, creeks, estuaries and streams in the Niger Delta region. The present study is the first systematic investigation of a selected group of organic constituents, mainly n-alkanes in sediments from coastal areas of Bonny, Imo, Qua Iboe and Warri rivers in the South-western and eastern parts of the Niger Delta region of Nigeria. The objectives are to: (a) quantitatively characterise n-alkanes in the solvent extractable lipids of sediments from the Niger Delta coastal areas, (b) use the multivariate statistical approach and compositional indices to identify the different sources of nalkane, and (c) provide additional insight into the prospective processes that modulate the flux of anthropogenic versus biogenic hydrocarbons ultimately accumulating in the Niger Delta coastal environment.

\section{Study Area}

The fan-shaped Niger Delta, which is the third largest in the world after the Mississippi (USA) and Pantanal (SouthWest Brazil), lies between latitudes (4 and 6$)^{0}$ north of the equator and longitudes ( 5 and 9$)^{0}$ east of the Greenwich
Meridian. The North-South extension, north of the equator, is expressly defined by the Great Atlantic Ocean in the South to Aboh (Delta State) in the North where River Niger forks in Rivers Nun and Forcados at a village called Obotor [17]. The East-West extension is from the boundary of the Bonny River to River Sapele, Delta State. The geographical Niger Delta is just about $25,640 \mathrm{~km}^{2}$ in size and is made up of $7,400 \mathrm{~km}^{2}$ low land area, $11,700 \mathrm{~km}^{2}$ fresh water swamp and $1,140 \mathrm{~km}^{2}$ salt barrier islands as ecological zones [17].

A simplified subdivision of the Niger Delta as fresh water zone, the mangrove and the coastal sand ridges was given by Mmom [18]. The Northern part of the fresh water zone is often regarded as an extension of the lower Niger flood plain [19], and it is very susceptible to the annual floods during the rainy season. The southern part of the fresh water zone and most of the mangrove are swampy and hardly rise above $10 \mathrm{~m}$ above mean sea level. This subzone covers a greater percentage of the Niger Delta. The strip of sand ridges and beaches lies close to the open sea and is bordered landwards by swamp areas with many creeks [17]. The Niger Delta region displays a typical dendritic drainage pattern. This is because most of the tributaries join their main rivers at oblique angles. For example, Taylor Creek joins the main River Nun at Polaku, and the Epie Creek joins the River Nun/Ekole at Yenagoa. This also implies that there are many confluence towns in the Niger Delta. There is also a near parallel type of drainage, for example, New Calabar/Bonny River, Brass/Nun River, Forcados/Escravos River, Taylor Creek/Epie Creek and Orashi River.

The vegetation of the Niger Delta coastal areas is characterized by extensive freshwater and mangrove swamps. The fresh water swamps consist of stilt rooted trees and shrubs. The main vegetation of the mangrove swamps of the Niger Delta is dominated by the red mangrove which forms more than nineteen percent (19\%) of the saline swamps [20]. The white mangroves occur scattered among the red mangroves and thrive in less water- logged places. Ferns, Nipa palms and herbs are found in areas where their salt content is not too high. The Niger Delta has provided the best conditions for the thriving of vegetation on the Nigerian coast. By some estimates, over sixty percent $(60 \%)$ of fishes caught between the Gulf of Guinea and Angola breed in the mangrove belt of the Niger Delta. The vegetation of the Niger Delta region is arranged in the form of storey/strata or layers [17]. There is the upper stratum occupied by very tall trees of heights $30 \mathrm{~m}$ and above; followed by the middle tier trees with heights of $15-20 \mathrm{~m}$, while the lower layer has trees and shrubs with heights below $12 \mathrm{~m}$. The upper layer is normally occupied by tall trees like the Iroko (Chlorophora excelsa), Mahogany (Khaya ivorensis), and Abura (Mitragyra macrophylla) [21]. Palm trees (Elaeis guineensis) and others occupy the middle layer. The availability of sunlight is also partly responsible for the growth of the tall plants as it provides them with the necessary solar energy for the photosynthetic process. 


\section{Materials and Methods}

\subsection{Sampling}

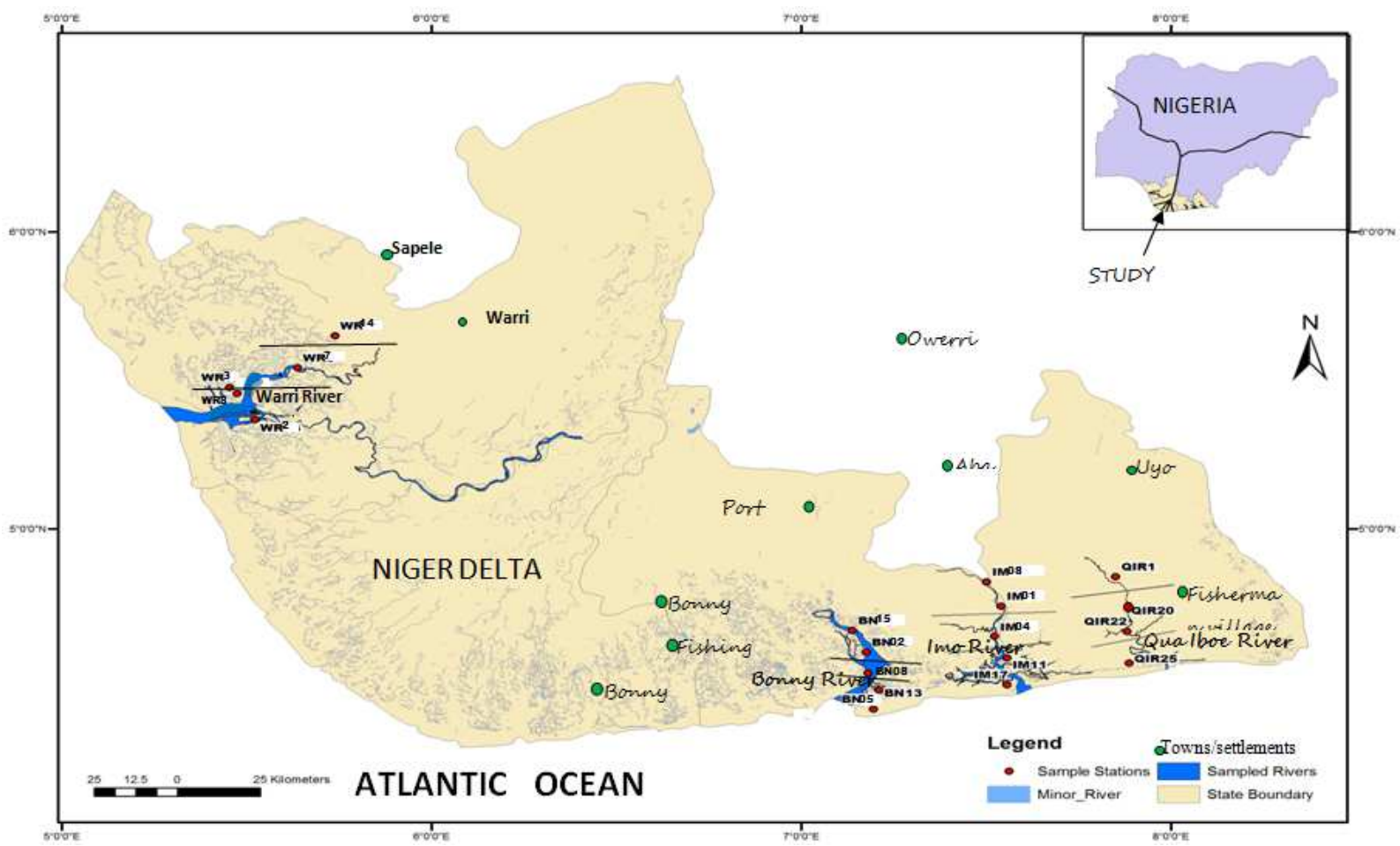

Fig 1. Map of study area showing sample stations

Table 1. Sample location and types of potential anthropogenic inputs

\begin{tabular}{|c|c|c|}
\hline $\begin{array}{l}\text { Sample } \\
\text { locations* }\end{array}$ & Zone & Potential anthropogenic inputs \\
\hline IM01 & Upper & \\
\hline \multicolumn{3}{|l|}{ IM08 } \\
\hline QIR1 & & $\begin{array}{l}\text { Domestic sewage as a result of } \\
\text { nucleated settlements and engine boat } \\
\text { pollution }\end{array}$ \\
\hline \multicolumn{3}{|l|}{ WR14 } \\
\hline \multicolumn{3}{|l|}{ BN15 } \\
\hline WR7 & Middle & \\
\hline \multicolumn{3}{|l|}{ WR3 } \\
\hline \multicolumn{3}{|l|}{ BN02 } \\
\hline \multicolumn{3}{|l|}{ IM04 } \\
\hline QIR22 & & $\begin{array}{l}\text { Agricultural waste, engine boat } \\
\text { pollution and fishing activities }\end{array}$ \\
\hline \multicolumn{3}{|l|}{ QIR20 } \\
\hline BN08 & & \\
\hline
\end{tabular}

\begin{tabular}{lll}
\hline $\begin{array}{l}\text { Sample } \\
\text { locations* }\end{array}$ & Zone & Potential anthropogenic inputs \\
\cline { 1 - 1 } IM17 & Lower & $\begin{array}{l}\text { Oil spills, oil pollution from ships and } \\
\text { engine boats, and untreated sewage }\end{array}$ \\
QIR25 & \\
BN05 & \\
WR8 & \\
WR2 & \\
\hline
\end{tabular}

$* \mathrm{IM}=\mathrm{Imo} ; \mathrm{BN}=$ Bonny; QIR $=$ Qua Iboe; WR $=$ Warri Rivers, respectively. $1,2,3$, etc refer to sampling stations

Samples of surface sediments were collected at different stations each along the coastal areas of Bonny, Qua Iboe, Warri and Imo rivers as depicted in the map of the study area (Fig. 1) using a modified grab sampler $\left(0.1 \mathrm{~m}^{2}\right)$. Samples were removed from the middle of the grab to avoid contact with the inner metallic surface of the grab sampler, wrapped in aluminium foil and stored frozen at - 4 ${ }^{0} \mathrm{C}$. The sampling was carried out based on the nature of potential anthropogenic inputs (Table1). Prior to extraction, the samples were freeze-dried, crushed and sieved through a 230 mesh $(<63 \mu \mathrm{m})$ sieve. 


\subsection{Extraction and Fractionation}

To minimize contamination, all glassware was cleaned with detergent solution, rinsed with distilled water, heated in an oven at $550^{\circ} \mathrm{C}$ for eight hours to combust traces of surface organic matter, and finally rinsed with ANALAR grade dichloromethane. The total organic carbon (TOC) contents were determined using a LECO CNS analyzer. Extraction of the crushed and sieved $(<63 \mu \mathrm{m})$ sediment samples for extractable organic matter (EOM) was carried out using a soxhlet apparatus [22]. The thimbles and the glass wool used in the extraction were soxhlet-extracted with dichloromethane for 20 minutes on a water bath. Powdered sediment sample $(50 \mathrm{~g})$ was then placed in the extracted thimble. The thimble with glass wool was filled with dichloromethane and extracted for $18 \mathrm{hrs}$. Extracts were desulphurized by addition of $30 \mathrm{~g}$ activated copper (copper immersed in $20 \mathrm{ml}$ of $0.1 \mathrm{M}$ concentrated hydrochloric acid for ten minutes) into the round-bottom flask during extraction. Extracts obtained were evaporated to near dryness using a vacuum evaporator. The weight of extracts was determined as a measure of the amount of extractable organic matter (EOM), made up of asphaltenes and maltenes. Precipitation of asphaltenes from the extractable organic matter (EOM) was carried out following the procedure described by Schoell and others [23] with a mixture (1:30) of dichloromethane /petroleum ether (b.p. $40-60^{\circ} \mathrm{C}$ ), and centrifuged at $3,000 \mathrm{rpm}$ for about $20 \mathrm{~min}$. The asphaltenes precipitated from EOM were discarded after weighing. The separation of maltenes obtained from the extracts into aliphatic, aromatic and hetero-fractions was carried out by column chromatography (column $30 \times 1.2 \mathrm{~cm})$ using activated silica gel $(20 \mathrm{~g}$ activated by heating in an oven for two hours at $400^{\circ} \mathrm{C}$ ) and alumina (neutral, $10 \mathrm{~g}$ activated by heating in an oven for two hours at $500^{\circ} \mathrm{C}$ ) on top of the silica gel. The concentrated extract $(2 \mathrm{ml})$ was carefully added to the top of the column already clamped to position. The saturated (aliphatic) fraction was eluted with $50 \mathrm{ml}$ hexane, while $200 \mathrm{ml}$ of 1:1 dichloromethane/hexane mixture was used for the elution of the aromatic fraction [24]. Finally, a mixture (1: $2,60 \mathrm{ml})$ of methanol/dichloromethane was used to remove the heterofractions.

\subsection{Gas Chromatography-Mass Spectrometry (GC-MS) Analysis}

The gas chromatography-mass spectrometry (GC-MS) analyses of the aliphatic and aromatic fractions from the sediment extracts were performed using an Agilent 6890 Series gas chromatograph (GC) interfaced to an Agilent 5973 Network Mass Selective Detector (MSD) and Agilent 7683 Series Injector. The GC Separation was achieved on a fused silica capillary column coated with DB $35(60 \mathrm{~m} \mathrm{x}$ $0.25 \mathrm{~mm}$ i.d., $0.25 \mu \mathrm{m}$ film thickness). The $\mathrm{GC}$ oven temperature was programmed from $50^{\circ} \mathrm{C}$ (isothermal for 1 minute) to $120^{\circ} \mathrm{C}$ at a rate of $20^{\circ} \mathrm{C} / \mathrm{min}$, then to $300^{\circ} \mathrm{C}$ at a rate of $3^{0} \mathrm{C} / \mathrm{min}$. The final temperature was held for 45 minutes. Helium was used as the carrier gas. Samples were introduced into the cool on-column injector under electronic pressure control. The GC column outlet was connected directly to the ion source of the mass spectrometer. The GC-MS interface was kept at $280{ }^{\circ} \mathrm{C}$, while the ion source and quadrupole analyzer were at 230 and $150^{\circ} \mathrm{C}$, respectively. The mass spectrometer was operated in the electron impact (EI) mode at $70 \mathrm{eV}$ ionization energy. Mass spectra were recorded from 45550 dalton $(0-40 \mathrm{~min})$ and $50-700$ dalton (above $40 \mathrm{~min})$. Data were acquired using the HP-MSD Chemstation Integrator. Individual compounds were identified by comparison of mass spectra with literature and library data. A procedural blank was run in sequence to sediment samples and background interferences were corrected.

\section{Results and Discussion}

Table 2. Geochemical parameters, n-alkane concentrations and compositional indices of surface sediments from coastal areas of Niger Delta.

\begin{tabular}{|c|c|c|c|c|c|c|c|c|c|c|c|c|}
\hline \multirow{2}{*}{ Zone } & \multirow{2}{*}{ Station } & \multirow{2}{*}{ TOC (\%) } & \multirow{2}{*}{$\operatorname{EOM}(\mathrm{mg} / \mathrm{kg})$} & \multicolumn{9}{|c|}{ n-alkane concentrations (mg/kg) } \\
\hline & & & & $\mathrm{C}_{16}$ & $\mathrm{C}_{17}$ & $\mathrm{C}_{18}$ & $\mathrm{C}_{21}$ & $\mathbf{C}_{22}$ & $\mathrm{C}_{23}$ & $\mathbf{C}_{24}$ & $\mathrm{C}_{25}$ & $\mathrm{C}_{26}$ \\
\hline \multirow[t]{5}{*}{ Upper } & IM01 & 3.18 & 2259 & nd & nd & nd & 0.64 & 2.01 & 2.06 & 1.96 & 3.32 & 1.99 \\
\hline & IM08 & 2.76 & 4489 & nd & nd & nd & 0.34 & 0.95 & 0.93 & 1.45 & 1.8 & 1.83 \\
\hline & QIR1 & 3.36 & 1296 & nd & nd & nd & 0.58 & 1.12 & 1.87 & 2.03 & 1.93 & 1.67 \\
\hline & WR14 & 1.26 & 1860 & nd & nd & nd & nd & nd & nd & nd & nd & nd \\
\hline & BN15 & 0.97 & 295 & nd & 0.16 & nd & 0.68 & 0.26 & 0.21 & 0.21 & 0.08 & 0.04 \\
\hline \multirow[t]{7}{*}{ Middle } & WR7 & 3.27 & 2345 & nd & nd & nd & nd & nd & nd & nd & nd & nd \\
\hline & WR3 & 2.98 & 6346 & nd & nd & nd & nd & nd & nd & nd & nd & nd \\
\hline & BN08 & 1.43 & 3725 & 0.08 & 0.82 & 0.76 & 0.46 & 0.17 & 0.47 & 0.15 & 0.08 & 0.01 \\
\hline & BN02 & 1.45 & 3094 & 0.2 & 1.32 & 0.41 & 0.37 & 0.88 & 0.96 & 0.29 & 0.37 & 0.45 \\
\hline & IM04 & 4.26 & 5144 & nd & nd & nd & 0.43 & 0.92 & 1.07 & 1.03 & 2.11 & 1 \\
\hline & QIR22 & 3.12 & 4707 & nd & nd & nd & 0.43 & 0.8 & 1.27 & 1.35 & 2.19 & 1.18 \\
\hline & QIR20 & 3.48 & 1024 & nd & nd & nd & 0.65 & 1.7 & 1.62 & 1.64 & 2.59 & 1.24 \\
\hline \multirow[t]{5}{*}{ Lower } & IM17 & 1.76 & 2373 & nd & nd & nd & 0.62 & 1.11 & 1.95 & 1.47 & 3.05 & 1.09 \\
\hline & IM11 & 1.96 & 3066 & nd & nd & nd & 0.78 & 1.47 & 2.08 & 1.7 & 3.1 & 1.51 \\
\hline & BN05 & 1.67 & 2923 & 0.67 & 2.76 & nd & 0.75 & 3.25 & 2.34 & 1.45 & 0.83 & 0.46 \\
\hline & WR8 & 2.71 & 1468 & nd & nd & nd & 0.82 & 1.29 & nd & 0.74 & nd & 6.75 \\
\hline & WR2 & 2.37 & 2354 & nd & nd & nd & 1.49 & 1.2 & 1.59 & 1.06 & 0.69 & 0.49 \\
\hline
\end{tabular}


Table 2. Continued

\begin{tabular}{|c|c|c|c|c|c|c|c|c|c|c|c|c|c|}
\hline \multirow{2}{*}{ Zone } & \multirow{2}{*}{ Station } & \multirow{2}{*}{ TOC (\%) } & \multirow{2}{*}{$\begin{array}{l}\text { EOM } \\
(\mathrm{mg} / \mathrm{kg})\end{array}$} & \multicolumn{10}{|c|}{ n-alkane concentrations (mg/kg) } \\
\hline & & & & $\mathbf{C}_{27}$ & $\mathrm{C}_{28}$ & $\mathrm{C}_{29}$ & $\mathrm{C}_{31}$ & TNA & $\mathbf{C}_{\text {range }}$ & $\mathbf{C}_{\max }$ & CPI & OEP & Paq \\
\hline \multirow[t]{5}{*}{ Upper } & IM01 & 3.18 & 2259 & 4.5 & 1.92 & 23.81 & 11.07 & 58.28 & $21-31$ & $\mathrm{C}_{29}$ & 8.16 & 1.52 & 0.16 \\
\hline & IM08 & 2.76 & 4489 & 2.16 & 1.56 & 1.61 & 1.04 & 13.71 & $21-31$ & $\mathrm{C}_{29}$ & 1.22 & 1.3 & 0.62 \\
\hline & QIR1 & 3.36 & 1296 & 1.52 & nd & 1.76 & 1.02 & 13.5 & $21-31$ & $\mathrm{C}_{24}$ & 1.68 & 1.4 & 0.68 \\
\hline & WR14 & 1.26 & 1860 & nd & nd & nd & nd & nd & nd & nd & & & \\
\hline & $\mathrm{BN} 15$ & 0.97 & 295 & nd & 0.01 & nd & nd & 1.65 & $17-28$ & $\mathrm{C}_{22}$ & 0.31 & 0.78 & 1 \\
\hline \multirow[t]{7}{*}{ Middle } & WR7 & 3.27 & 2345 & nd & nd & nd & nd & nd & nd & nd & & & \\
\hline & WR3 & 2.98 & 6346 & nd & nd & nd & nd & nd & nd & nd & & & \\
\hline & BN08 & 1.43 & 3725 & nd & 0.05 & nd & nd & 3.05 & $16-28$ & $\mathrm{C}_{17}$ & 0.5 & 3.16 & 1 \\
\hline & BN02 & 1.45 & 3094 & nd & 0.12 & nd & nd & 5.32 & $16-28$ & $\mathrm{C}_{29}$ & 0.9 & 1.18 & 1 \\
\hline & IM04 & 4.26 & 5144 & 2.98 & 1.06 & 23.68 & 12.4 & 46.68 & $21-31$ & $\mathrm{C}_{29}$ & 13.32 & 1.85 & 0.12 \\
\hline & QIR22 & 3.12 & 4707 & 2.19 & 1.37 & 2.74 & 7.12 & 20.64 & $21-31$ & $\mathrm{C}_{31}$ & 3.65 & 1.81 & 0.56 \\
\hline & QIR20 & 3.48 & 1024 & 2.81 & nd & 7.96 & 4.68 & 24.89 & $21-31$ & $\mathrm{C}_{29}$ & 6.26 & 1.46 & 0.35 \\
\hline \multirow[t]{6}{*}{ Lower } & IM17 & 1.76 & 2373 & 4 & 1.44 & 23.21 & 17.63 & 55.57 & $21-31$ & $\mathrm{C}_{29}$ & 11.97 & 2.18 & 0.18 \\
\hline & IM11 & 1.96 & 3066 & 3.84 & 1.73 & 28.11 & 17.02 & 61.34 & $21-31$ & $\mathrm{C}_{29}$ & 10.54 & 1.88 & 0.16 \\
\hline & QIR25 & 0.44 & 672.7 & 4.9 & 3.55 & 7.69 & 4.85 & 47.4 & $21-31$ & $\mathrm{C}_{29}$ & 1.61 & 1.1 & 0.55 \\
\hline & BN05 & 1.67 & 2923 & nd & 0.1 & 0.05 & nd & 12.66 & $16-29$ & $\mathrm{C}_{17}$ & 1.6 & 0.83 & 0.7 \\
\hline & WR8 & 2.71 & 1468 & 1.05 & nd & 2.11 & 1.84 & 14.6 & $21-31$ & $\mathrm{C}_{26}$ & 0.67 & 0.4 & \\
\hline & WR2 & 2.37 & 2354 & nd & nd & 0.71 & 0.87 & 8.1 & $21-31$ & $\mathrm{C}_{26}$ & 1.46 & 1.67 & 0.76 \\
\hline
\end{tabular}

TNA $=$ Total n-alkanes, $\mathrm{CPI}=$ Carbon preference index : calculated according to [22] as $\left(\mathrm{C}_{23}+\mathrm{C}_{25}+\mathrm{C}_{27}+\mathrm{C}_{29}+\mathrm{C}_{31}\right) /\left(\mathrm{C}_{24}+\mathrm{C}_{26}+\mathrm{C}_{28}+\mathrm{C}_{30}\right)$, Paq = n-alkane proxy : calculated according to [23] as $\left(\mathrm{C}_{23}+\mathrm{C}_{25}\right) /\left(\mathrm{C}_{23}+\mathrm{C}_{25}+\mathrm{C}_{29}+\mathrm{C}_{31}\right)$, OEP $=$ Odd even predominance $\left(\mathrm{C}_{21}-\mathrm{C}_{25}\right)$, $\mathrm{Cmax}=$ Carbon maximum (n-alkane with maximum concentration), $\mathrm{TOC}=$ Total organic carbon, $\mathrm{EOM}=$ Extractable organic matter

Table 3. Mean n-alkane concentrations for the sediments in the different zones of the study area.

\begin{tabular}{llllll}
\hline & & \multicolumn{5}{c}{$\begin{array}{l}\text { Average concentration } \\
\text { (mg/kg) }\end{array}$} \\
\cline { 3 - 6 } & & & Zone \\
\hline Compound & MW & $\begin{array}{l}\text { Molecular } \\
\text { Formula }\end{array}$ & Upper & Middle & Lower \\
\hline n-Hexadecane & 226 & $\mathrm{C}_{16} \mathrm{H}_{34}$ & nd & 0.04 & 0.11 \\
n-Heptadecane & 240 & $\mathrm{C}_{17} \mathrm{H}_{36}$ & 0.04 & 0.31 & 0.46 \\
n-Octadecane & 254 & $\mathrm{C}_{18} \mathrm{H}_{38}$ & nd & 0.17 & nd \\
n-Heneicosane & 296 & $\mathrm{C}_{21} \mathrm{H}_{44}$ & 0.46 & 0.33 & 0.95 \\
n-Docosane & 310 & $\mathrm{C}_{22} \mathrm{H}_{46}$ & 0.87 & 0.63 & 2.14 \\
n-Tricosane & 324 & $\mathrm{C}_{23} \mathrm{H}_{48}$ & 1.01 & 0.77 & 2.06 \\
n-Tetracosane & 338 & $\mathrm{C}_{24} \mathrm{H}_{50}$ & 1.13 & 0.64 & 2.01 \\
n-Pentacosane & 352 & $\mathrm{C}_{25} \mathrm{H}_{52}$ & 1.43 & 1.05 & 2.21 \\
n-Hexacosane & 366 & $\mathrm{C}_{26} \mathrm{H}_{54}$ & 1.11 & 0.55 & 2.56 \\
n-Heptacosane & 380 & $\mathrm{C}_{27} \mathrm{H}_{56}$ & 1.64 & 1.14 & 2.3 \\
n-Octacosane & 394 & $\mathrm{C}_{28} \mathrm{H}_{58}$ & 0.7 & 0.37 & 1.14 \\
n-Nonacosane & 408 & $\mathrm{C}_{29} \mathrm{H}_{60}$ & 5.44 & 4.91 & 10.31 \\
\hline n-Hentiracontane & 436 & $\mathrm{C}_{31} \mathrm{H}_{61}$ & 2.63 & 3.46 & 6.37 \\
\hline
\end{tabular}

The sampling stations, extractable organic matter (EOM), percentage total organic carbon (\% TOC) contents, different $\mathrm{n}$-alkane concentrations, total n-alkane (TNA) concentrations as well as some source diagnostic indices derived from n-alkane compositions are presented in Table 2. The average concentration for each n-alkane in every zone of the Niger Delta study area is given in Table 3.

\subsection{Geochemical Parameters}

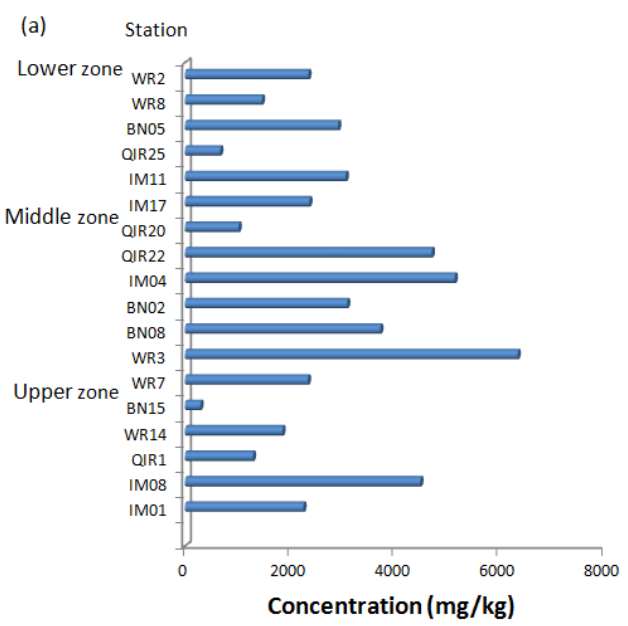


(b)

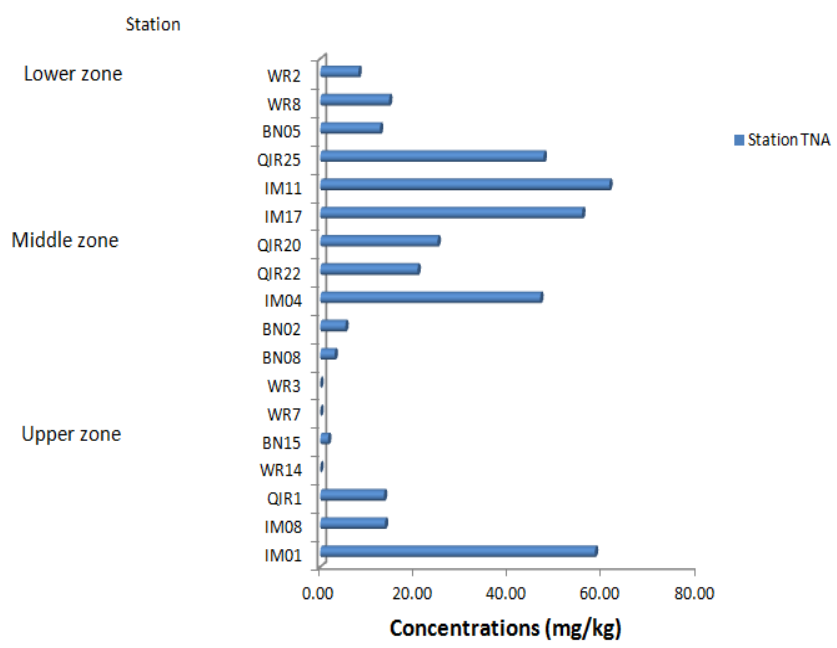

Fig 2. Variations in (a) Extractable organic matter (EOM); (b) Total nalkane (TNA) in the study area.

Variations in extractable organic matter (EOM) are depicted in Fig.2a with a maximum of $6346 \mathrm{mg} / \mathrm{kg}$ dry sediment weight for station WR3 and a minimum value of $212 \mathrm{mg} / \mathrm{kg}$ for station BN13 (Table 2). Most stations at the middle zone (e.g. stations IM04, QIR22, BN02 and WR3 in Fig.2a) recorded high EOM values, while some stations (e.g. BN13, WR8 and QIR25) at the lower zone recorded relatively low EOM values. Stations at the upper zone of the study area recorded intermediate EOM values. EOM compositional variations in our samples may be attributed to differences in oxidative conditions at the water-sediment interface, salinity of the depositional environment, quantity and quality of organic matter sources. The percentage total organic carbon (\%TOC) contenting for the sediments ranged from 0.44 to $4.26 \%$ (mean $2.36 \pm 1.03$ ), maximizing for station IM04 (Table 2).

\subsection{Normal Alkanes}

Abundance

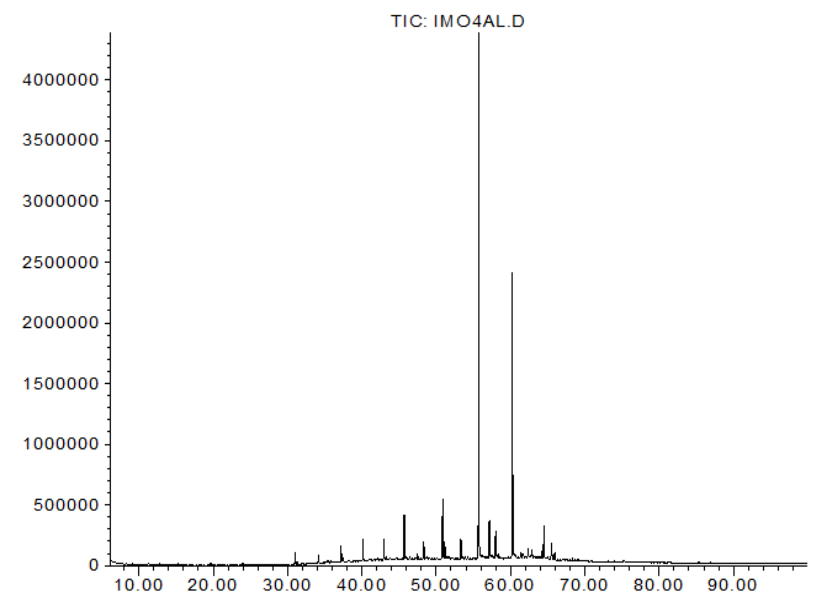

(a)

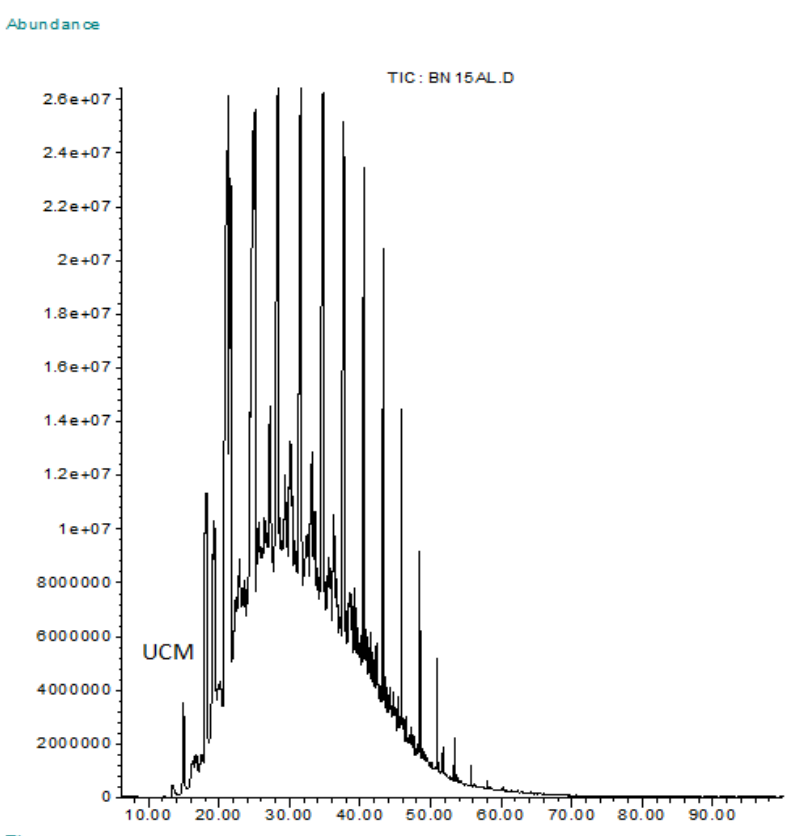

(b)

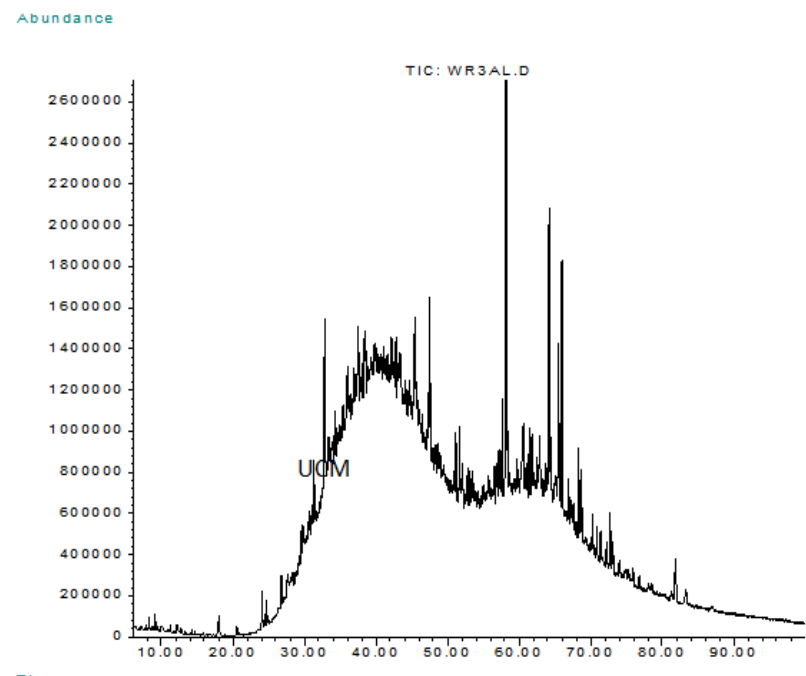

(c)

Fig 3. Examples of Gas Chromatograms (TIC) of n-alkane distributions for surface sediments from Niger Delta coastal areas showing (a) terrestrial, (b) petroleum and (c) sewage input sources, for stations IM04 (in middle zone), WR3 and BN15 (in upper zone), respectively.

Normal alkanes were present in all stations from the lower zone, but were not detected in stations WR14 in the upper zone, WR7 and WR3 in the middle zone. Most stations in the study area recorded n-alkanes in the range of $\mathrm{C}_{21}$ to $\mathrm{C}_{31}$. The total $\mathrm{n}$-alkane concentrations in the entire study area varied between $1.65-61.34 \mathrm{mg} / \mathrm{kg}$ dry weight (Table 2), with overall average of $21.52 \pm 22.00$. Variations in the total n-alkane (TNA) concentrations are presented in Fig. 2b. The mean n-alkane concentrations for the sediments in the upper, middle and lower zones of the study area ranged from $0.04-5.44 \mathrm{mg} / \mathrm{kg}, 0.04-4.91 \mathrm{mg} / \mathrm{kg}$ and $0.11-10.31 \mathrm{mg} / \mathrm{kg}$, respectively (Table 3 ). Examples of $\mathrm{n}-$ alkane distribution patterns in some stations from the study 
area indicating different contributions from anthropogenic and biogenic/terrestrial sources to sedimentary organic matter are depicted in Fig. 3. The n-alkane envelopes depicted unimodal distribution for sediments from Bonny coastal areas with evidence of petroleum contamination (presence of UCM, example Fig. 3b). The $\mathrm{C}_{16}-\mathrm{C}_{18} \mathrm{n}$ alkanes, maximizing at $\mathrm{C}_{17}$, detected in stations along the Bonny coastal areas possibly originated from both terrestrial/biogenic and anthropogenic sources, with a stronger biogenic signal. Higher-plant n-alkanes in the range $\mathrm{C}_{27}-\mathrm{C}_{31}$ were barely present in samples from Bonny coastal areas giving supportive evidence to other possible biogenic organic matter inputs such as submerged/floating macrophytes. The n-alkane distributions in stations from Imo (e.g. Fig.3a) and Qua Iboe coastal areas, in the range $\mathrm{C}_{21}-\mathrm{C}_{3 \mathrm{I}}$ and maximizing at $\mathrm{C}_{29}$ at most stations, are comparable and reflect predominant terrestrial/biogenic source input from higher plants which dominate the coastal vegetation of these rivers. Normal n-alkanes in the range $\mathrm{C}_{16}-\mathrm{C}_{31}$ were not detected in stations WR3, WR7, and WR14 from coastal areas of the Warri river in Southwestern part of the Niger Delta region (Table 2). The GC traces (e.g. Fig. 3c) of these stations are erratic and compare closely with that reported for source input from sewage [9].

An odd/even predominance (OEP) in the n-alkanes $>\mathrm{C}_{23}$ has often been used as a marker for a direct input of terrestrial plant waxes into geological and environmental samples [7]. Conversely, an even/odd predominance has been reported to be associated with recent sediments having organic matter input from phytoplanktonic organisms such as diatoms and some bacteria [15], [25]. Even-numbered nalkane predominances are less common. Slight even carbon number n-alkane predominances or smooth distributions in the $n-C_{20}-C_{30}$ range have been ascribed to reductive processes or bacterial inputs [25]. Our results, however, differ slightly from the even/odd predominance of nalkanes $\left(\mathrm{C}_{14}-\mathrm{C}_{22}\right)$ reported for Cretaceous sediments from the upper Benue Trough, Nigeria which was tentatively attributed to hyper salinity [26]. In this study, the odd/even predominances in the $n-C_{17}-C_{31}$ range (Table 2) observed for most stations could be traced to mixed origin of terrestrial/biogenic, bacterial/microbial and anthropogenic organic source inputs, with stronger terrestrial/biogenic signal in stations from Imo, Qua Iboe and Bonny than Warri coastal areas.

The identification of the homologous n- alkanes in the hydrocarbon fractions allowed the determination of the carbon preference index (CPI) and Carbon maximum $\left(\mathrm{C}_{\max }\right)$ for each sample set, which give supportive evidence for the relative incorporation of the different $n$-alkane sources. The CPI, a measure of biologically synthesized n-alkanes [27], [28], indicates the relative contributions of n-alkanes from natural (biogenic/terrestrial; CPI $>1$ ) compared to anthropogenic $(\mathrm{CPI}<1)$ sources. The carbon preference index (CPI) was calculated according to Zhu and others [29] using the same odd-carbon and even-carbon number nalkane concentrations in the respective samples as follows:

$$
\mathrm{CPI}=\left(\mathrm{C}_{23}+\mathrm{C}_{25}+\mathrm{C}_{27}+\mathrm{C}_{29}+\mathrm{C}_{31}\right) /\left(\mathrm{C}_{24}+\mathrm{C}_{26}+\mathrm{C}_{28}+\mathrm{C}_{30}\right)
$$

Values of CPI ranged from 0.31 - 13.32 for the entire stations, with maximum value for station IM04 (Table 2). Stations from Imo and Qua Iboe coastal areas recorded CPI values greater than one, suggesting terrigenous/biogenic sedimentary sources of n-alkanes. Conversely, the calculated CPI values for stations BN02, BN08, BN15 and WR8 were less than one, indicating a relatively higher proportion of n-alkanes from anthropogenic (mostly petroleum ) sources. These results corroborate earlier reports by other researchers [13], [30]. In order to evaluate the origin of long-chain n-alkanes (i.e. whether the longchain n-alkanes are derived from either higher plant waxes or macrophytes) in our coastal sediments, the parameter, Alkane Proxy $\left(\mathrm{P}_{\mathrm{aq}}\right)$ was calculated according to [23] as follows:

$$
\mathrm{P}_{\mathrm{aq}}=\left(\mathrm{C}_{23}+\mathrm{C}_{25}\right) /\left(\mathrm{C}_{23}+\mathrm{C}_{25}+\mathrm{C}_{29}+\mathrm{C}_{31}\right)
$$

Values of $\mathrm{P}_{\mathrm{aq}}$ (Table 2) ranged from $0.12-1.00$ for the entire sample suite. $\mathrm{P}_{\mathrm{aq}}$ values ranging from 0.01 to 0.23 are linked to terrestrial plant waxes whereas those in the range of 0.48 to 0.94 are associated with submerged/floating species of macrophytes [30]. Results of this study showed the importance of higher plant contribution to long-chain nalkanes in almost all stations from Imo river coastal areas. Most stations from Bonny, Qua Iboe and stationWR2 from Warri coastal areas appeared to have more biogenic contributions to long-chain sedimentary n-alkanes from submerged/floating species of macrophytes.

\subsection{Source Evaluation of Contaminant N-Alkanes (Factor Analysis)}

For a better understanding of the principal sources and biogeochemical processes responsible for the sedimentary n-alkanes in coastal sediments from the Niger Delta region of Nigeria, varimax rotated factor analysis using Statistica version 7.0 was carried out on the data set. Factor analysis provides a description of the multivariate data set in terms of a few orthogonal end members (factors), which account for the variance within the data set. The varimax rotated factor analysis was calculated using eigen values greater than 1.0 and sorted by results having values greater than 0.6 being considered significant influences towards the principal sources. The results of sorted rotated factor analysis along with eigen values and percentages of variation are presented in Table 4 . Three factors or principal components (PCs) explained 86.96\%, 93.16\%, 90.99\% and $91.31 \%$ for the n-alkanes in stations from Warri, Imo, Bonny and Qua Iboe coastal areas, respectively with different percentages of total variance for the entire data structure. 
Table 4. Varimax rotated factor analyses of n-alkanes and compositional indices for Factors 1,2 and 3 are terrestrial/biogenic, anthropogenic and microbial sources

\begin{tabular}{|c|c|c|c|c|c|c|c|c|c|c|c|c|}
\hline \multirow[b]{3}{*}{ Parameters } & \multicolumn{3}{|c|}{ (a) Imo coastal sediments } & \multicolumn{3}{|c|}{ (b)Bonny coastal sediments } & \multicolumn{3}{|c|}{ (c) Warri coastal sediments } & \multicolumn{3}{|c|}{$\begin{array}{l}\text { (d) Qua Iboe coastal } \\
\text { sediments }\end{array}$} \\
\hline & \multicolumn{12}{|c|}{ (Marked loadings are $>.600000$ ) } \\
\hline & Factor & Factor & Factor & Factor & Factor & Factor & Factor & Factor & Factor & Factor & Factor & Factor \\
\hline & 1 & 2 & 3 & 1 & 2 & 3 & 1 & 2 & 3 & 1 & 2 & 3 \\
\hline $\mathrm{C}_{\text {MAX }}$ & 0.963 & -0.139 & 0.066 & 0.935 & 0.149 & 0.228 & 0.208 & -0.543 & 0.766 & 0.962 & 0.000 & 0.168 \\
\hline CPI & 0.975 & -0.054 & 0.018 & 0.939 & 0.147 & 0.215 & 0.208 & -0.541 & 0.767 & 0.959 & 0.016 & 0.184 \\
\hline OEP & 0.975 & -0.043 & 0.016 & 0.937 & 0.145 & 0.226 & 0.172 & -0.925 & 0.017 & 0.958 & 0.016 & 0.189 \\
\hline Paq & 0.028 & -0.047 & 0.018 & 0.936 & 0.144 & 0.229 & 0.101 & 0.232 & 0.944 & 0.958 & 0.015 & 0.188 \\
\hline$n-C_{16}$ & -0.975 & -0.047 & 0.018 & 0.621 & -0.128 & 0.628 & -0.959 & 0.028 & 0.110 & 0.958 & 0.015 & 0.188 \\
\hline $\mathrm{C}_{17}$ & -0.975 & -0.047 & 0.018 & 0.621 & 0.153 & 0.228 & -0.959 & 0.028 & 0.110 & 0.958 & 0.015 & 0.188 \\
\hline $\mathrm{C}_{18}$ & -0.975 & -0.047 & 0.018 & 0.266 & 0.095 & 0.927 & -0.959 & 0.028 & 0.110 & 0.958 & 0.015 & 0.188 \\
\hline $\mathrm{C}_{21}$ & 0.975 & -0.050 & 0.018 & 0.936 & 0.148 & 0.226 & 0.208 & -0.544 & 0.765 & 0.957 & 0.012 & 0.193 \\
\hline $\mathrm{C}_{22}$ & 0.975 & -0.049 & 0.022 & 0.932 & 0.154 & 0.235 & 0.209 & -0.547 & 0.762 & 0.954 & 0.000 & 0.208 \\
\hline $\mathrm{C}_{23}$ & 0.975 & -0.056 & 0.018 & 0.934 & 0.152 & 0.230 & 0.172 & -0.925 & 0.017 & 0.954 & 0.006 & 0.206 \\
\hline $\mathrm{C}_{24}$ & 0.975 & -0.048 & 0.018 & 0.934 & 0.149 & 0.231 & 0.208 & -0.546 & 0.764 & 0.953 & 0.002 & 0.213 \\
\hline $\mathrm{C}_{25}$ & 0.975 & -0.058 & 0.020 & 0.935 & 0.148 & 0.228 & 0.172 & -0.925 & 0.017 & 0.955 & -0.001 & 0.206 \\
\hline $\mathrm{C}_{26}$ & 0.976 & -0.042 & 0.018 & 0.936 & 0.147 & 0.227 & 0.210 & -0.576 & 0.739 & 0.953 & 0.003 & 0.211 \\
\hline $\mathrm{C}_{27}$ & 0.974 & -0.062 & 0.025 & -0.936 & -0.146 & -0.227 & 0.082 & 0.233 & 0.946 & 0.956 & -0.003 & 0.201 \\
\hline $\mathrm{C}_{28}$ & 0.975 & -0.047 & 0.017 & -0.936 & 0.146 & 0.226 & -0.959 & -0.028 & -0.110 & 0.466 & 0.348 & 0.147 \\
\hline $\mathrm{C}_{29}$ & 0.924 & -0.283 & 0.123 & 0.492 & -0.298 & -0.339 & 0.209 & -0.553 & 0.758 & 0.955 & -0.030 & 0.204 \\
\hline $\mathrm{C}_{31}$ & 0.955 & -0.205 & 0.035 & -0.936 & -0.146 & -0.227 & 0.209 & -0.552 & 0.759 & 0.962 & -0.011 & 0.166 \\
\hline \multicolumn{13}{|c|}{ Extraction: Principal Components } \\
\hline & $\begin{array}{l}\% \text { total } \\
\text { variance }\end{array}$ & $\begin{array}{l}\text { Eigen } \\
\text { values }\end{array}$ & $\begin{array}{l}\% \\
\text { Cummul. }\end{array}$ & $\begin{array}{l}\% \text { total } \\
\text { variance }\end{array}$ & $\begin{array}{l}\text { Eigen } \\
\text { values }\end{array}$ & $\begin{array}{l}\% \\
\text { Cummul. }\end{array}$ & $\begin{array}{l}\% \text { total } \\
\text { variance }\end{array}$ & $\begin{array}{l}\text { Eigen } \\
\text { values }\end{array}$ & $\begin{array}{l}\% \\
\text { Cummul. }\end{array}$ & $\begin{array}{l}\% \text { total } \\
\text { variance }\end{array}$ & $\begin{array}{l}\text { Eigen } \\
\text { values }\end{array}$ & $\begin{array}{l}\% \\
\text { Cummul. }\end{array}$ \\
\hline 1 & 75.14 & 31.56 & 75.14 & 71.48 & 30.02 & 71.48 & 45.38 & 19.06 & 45.38 & 71.07 & 29.85 & 71.07 \\
\hline 2 & 13.95 & 5.86 & 89.08 & 11.60 & 4.87 & 83.09 & 29.36 & 12.33 & 74.74 & 15.36 & 6.45 & 86.43 \\
\hline 3 & 4.08 & 1.71 & 93.16 & 7.90 & 3.32 & 90.99 & 12.22 & 5.13 & 86.96 & 4.87 & 2.05 & 91.31 \\
\hline
\end{tabular}

Factor 1, which was positively loaded with CPI, accounted for $75.14 \%, 71.48 \%$ and $71.07 \%$ of the total variance for $n$-alkanes in stations from coastal areas of Imo, Bonny and Qua Iboe rivers, respectively. This factor was attributed to biogenic/terrestrial sources. On the other hand, factor 1 accounted for only $45.38 \%$ of the total variance for n-alkanes in stations from coastal areas of Warri River with negative loading on CPI, thus indicating relatively weak terrestrial/biogenic contributions to sedimentary n-alkanes in stations from these areas. The second factor obtained using n-alkanes and compositional indices explained $13.95 \%, 11.61 \%, 29.36 \%$ and $15.36 \%$ of the total variance for n-alkanes in stations from coastal areas of Imo, Bonny, Warri and Qua Iboe rivers, respectively; and was found to be negatively associated with compositional indices (CPI, OEP, Paq) in the entire data structure. This factor was attributed to petrochemical sources. The third factor contributed $4.08 \%, 7.90 \%, 12.22 \%$ and $4.88 \%$ of the total variance for $n$-alkanes in stations from coastal areas of Imo, Bonny, Warri and Qua Iboe rivers, respectively. This factor, which was negatively loaded with CPI, OEP and Paq, was attributed to microbial/bacterial source inputs to sedimentary organic matter.

\section{Conclusion}

Characterization of surface sediments from coastal areas of four rivers in south-eastern and western parts of an industrialized and urban Niger Delta region of Nigeria has confirmed the presence of aliphatic hydrocarbons which are source specific from anthropogenic and natural (terrestrial/biogenic) indicators. The anthropogenic components comprise mainly petrochemical residues which were confirmed by the UCM, $\mathrm{C}_{\max }$ pristane, phytane, CPI. 
The terrestrial components consisted of wax n-alkanes with $\mathrm{C}_{29}$ predominance in most of the samples. The major biogenic input to the bulk hydrocarbons in the study area are of a microbial origin. This study has demonstrated the use of source partitioning modeling using multivariate statistical analysis (factor analyses) to reduced chemical diagnostic indices based on chemical fingerprinting into three principal components (PCs) which confirmed inputs from biogenic, anthropogenic and microbial/bacterial sources.

\section{References}

[1] Wang ZD, Fingas M, Page, DS, 1999. Oil spill identification. Journal of Chromatography. A 843: 369 - 411.

[2] Wang ZD, Stout, SA, Fingas M, 2006. Forensic fingerprinting of biomarkers for oil spill characterization \& source identification. Environmental Forensics, 7(2): 105146.

[3] Page DS, Boehm PD, Douglas GS, Bence AE, 1995. Identification of hydrocarbon sources in the benthic sediments of Prince William Sound and the Gulf of Alaska following the Exxon Valdez oil spill. In: Wells, P.G.,

[4] Page D S, Boehm PD, Douglas GS, Bence AE, Burns WA, Mankiewiez PJ, 1996. The natural petroleum hydrocarbon background in subtidal sediments of Prince William Sound, Alaska, USA. Environmental Toxicology and Chemistry, 15: 1266-1281.

[5] Boehm PD, Douglas GS, Brown JS, Page DS, Bence AE, Burns WA, Mankieweiz, PJ, 2000. Comments on "Natural hydrocarbon background in benthic sediments of Prince William Sound, Alaska: Oil vs coal”. Environmental Science and Technology, 34: 2064-2065.

[6] Ekpo BO, Fubara EP, Ekpa OD, Marynowski HL, 2012. Distributions of fossil fuel biomarkers in sediments as proxies for petroleum contamination of coastal environment of the Niger Delta, Southeastern Nigeria. Journal of Applied Sciences in Environmental Sanitation, 7(2): 75-86.

[7] Simoneit BRT, 1978. The organic chemistry of marine sediments. In: Riley J.P. and Chester R (eds). Chemical oceanography, Vol. 7, $2^{\text {nd }}$ edition, Academic Press, New York, pp 233-311.

[8] Mazurek M, Simoneit BRT, 1983. Characterization of biogenic and petroleum-derived organic matter in aerosols over remote rural and urban areas. In:Keith L.H.(ed), Identification and analysis of organic pollutants in air, American Chemical Society Symposium, Ann Arbor Science Publishers/Butterworth, Woburn, MA. 71: 92-108.

[9] Aboul-Kassim TAT, Simoneit BRT, 1996. Lipid geochemistry of surficial sediments from the coastal environment of Egypt I. Aliphatic hydrocarbonscharacterization and sources. Marine Chemistry, 54: 135158 .

[10] Pisani O, Oros DR, Oyo-Ita OE, Ekpo BO, Jaffé R, Simoneit BRT, 2013. Biomarkers in surface sediments from the Cross River and estuary system, SE Nigeria: Assessment of organic matter sources of natural and anthropogenic origins. Applied Geochemistry, 31: 239-250.
[11] Camacho-Ibar V, Aveytua-Alcazar L, Carriquiry J, 2003. Fatty acid reactivities in sediment cores from the Northern Gulf of California. Journal of Organic Geochemistry, 34: 425-439.

[12] Dickhut RM, Canuel EA, Countway RE, 2003. PAHs distributions and associations with organic matter in surface waters of the York River, VA Estuary. Journal of Organic Geochemistry, 34: 209-224.

[13] Oyo-lta OE, Ekpo BO, Oros DR, Simoneit BRT, 2010. Distribution and sources of aliphatic hydrocarbons and ketones in surface sediments from the Cross River estuary, S.E. Niger Delta, Nigeria. Journal of Applied Sciences in Environmental Sanitation, 5(1):13-24.

[14] Fubara EP, Ekpo BO, Ekpa OD, Marynowski Hab L, 2012. Predominances and source implications of even n-alkenes in surface sediments from coastal areas of Niger Delta, Nigeria. International Journal of Basic \& Applied Sciences IJBASIJENS. 2(2): 68-79.

[15] Ekpo BO, Oyo-Ita OE, Wehner H, 2005. Even nalkane/alkene predominances in surface sediments from the Calabar River, S.E. Niger Delta, Nigeria. Naturwissenschaften, 92 (7): 341-346.

[16] Oyo-lta OE, Ekpo BO, Umana US, Simoneit BRT, 2006. Predominance of $n$-docosane/docosene as molecular indicators of microbial and recent biogenic organic matter incorporation into surface sediments of Cross River Estuary, S.E Niger Delta of Nigeria. Journal of Environmental Sciences, 5: 43-48.

[17] Tamuno TT, 2008. The Geographical Niger Delta. Proceedings of the International Conference on the Nigerian state, Oil Industry and the Niger Delta. pp 916-930.

[18] Mmom PC, 2003. The Niger Delta- A spatial perspective to its development. Zelon Enterprises, Port Harcourt.

[19] Udo RK, 1975. A Comprehensive geography of West Africa. Heinemann Educational Books Ltd., Ibadan.

[20] Nwilo PC, Badejo OT, 2008. Impacts and management of oil spill in Nigerian coastal environment. Proceedings of the International Conference on the Nigerian State, Oil Industry and the Niger Delta. $p p 1217-1232$.

[21] Nyanayo BL, 2007. Plants from the Niger Delta. Onyoma Research Publications, Port Harcourt.

[22] EPA-3540, 1986. Soxhlet extraction. In:Test Method Evaluation Solid Waste Physical/Chemical Methods, Laboratory Manual, Washington DC, Environmental Protection Agency, 1986, v. 1-B.

[23] Schoell M, Teschner M, Wehner H, Durand B and Oudin J L (1983). Maturity related biomarkers and stable isotope variation and their application to oil/source rock correlation in the Mahakam Delta, Kalimatan. In: Bjoroy M. (ed.), Advances in Organic Geochemistry 1981, Chichester, Wiley. pp156-163.

[24] Meniconi MG, Barbanti SM, 2007. Evaluation of hydrocarbon sources in Guanabara Bay, Brazil. In: Wang Z and Stout SA (eds.). Oil spill environmental forensics: Fingerprinting and source identification, Elsevier, USA. pp. 505-536. 
[25] Elias VO, Simoneit BRT, Cardoso JN, 1997. Even n-alkane predominances on the Amazon Shelf and a Northeast Pacific Hydrothermal System. Naturwissenchaften, 84: 415-420.

[26] Pearson MJ, Obaje NG, 1999. Onocerane and other triterpenoids in Late Cretaceous sediments from the Upper Benue Trough, Nigeria: Tectonic and palaeoenvironmental implications. Organic Geochemistry, 30: 583-592.

[27] Simoneit BRT, Sheng G, Chen X, Fu J, Zhang H, Xu Y, 1991. Molecular marker study of extractable organic matter in aerosols from the urban areas of China. Atmospheric Environment, 25A: 2111-2129.

[28] Ekpo BO, Wehner H. 2009. Geochemical Imprints of
Petroleum Pollution of Surface Sediments from the Calabar River, Southeastern Niger Delta of Nigeria. In: River Sediments ISBN: 978-1-60741-437-7. Editor: Greig Ramsey and Seoras McHugh, Nova Science Publishers, Inc: 129-150.

[29] Zhu Y, Liu H, Cheng H, Xi Z, Liu X, Xu X, 2005. The distribution and source apportionment of aliphatic hydrocarbons in soils from the outskirts of Beijing. Organic Geochemistry, 3: 475-483.

[30] Ficken KJ, Li B, Swain DE, Eglinton G, 2000. An n-alkane proxy for sedimentary input of submerged/floating fresh water aquatic macrophytes. Organic Geochemistry. 31: 745759 . 